\title{
9 New barriers and new possibilities
}

\section{Confronting language inaccessibility in and around a pandemic}

\author{
Liz Adams Lyngbäck, Mia Larsdotter and Enni \\ Paul
}

In this chapter, we will explore cases of language inaccessibility through examples from before and during the COVID-19 pandemic. The examples illustrate inaccessibility of information during daily press conferences, hindrances to, as well as possibilities of, digitalisation of education, and language barriers emerging through the widespread use of closed captioning for prerecorded online lectures. Although the examples are from Sweden, the issue of language inaccessibility considering the particular groups affected - the deaf, the hard-of-hearing, and people with cognitive disabilities - will bring together aspects of what perpetuates and pervades inaccessibility in respect to communication that are relevant for a wider audience.

The pandemic has had far-reaching consequences due to the precautions and restrictions to keep the virus from spreading, affecting everyone around the globe. Several initiatives to document how the developing pandemic has affected accessibility, and in particular people with disabilities, have been launched (cf. Kritfunk, 2020; Johansson, Forsell \& Gustavsson, 2021). With people blocked or hindered in their movement, the duty to provide and protect citizens in society has led to increasing use of online working, online health and social services and online education. Communication via mobile and digital technology has suddenly revealed underutilised avenues of accessibility for some. The potential consequences for all citizens during the COVID-19-pandemic offer us a lens which partially reflects restrictions we all have experienced but also refracts an image of how only certain types of bodies have power over accessibility. With this unequal distribution of influence, some groups are affected more severely due to the intersection of language issues with ableism. In this chapter, using critical research perspectives, we will examine: (1) how ideas about ability lead to (re)-oppression in the forms of ableism, linguicism and audism, (2) when and how changes reversing language inaccessibility can come about, and (3) how oppression, once it is known, still doesn't change practices.

To do this, we will employ an analysis of how organisations in Sweden were forced to solve problems in real time. We made observations of practices we were directly involved with: the move to online instruction, meetings in organisations of all kinds moved to video conferencing platforms and language

DOI: $10.4324 / 9781003120452-12$ 
access in mass media. These observations frame the three examples in the chapter and serve as 'teachers of accessibility' in the form of real events, real discrimination and real lives (see also Patrick Kermit's chapter in this book).

The method of ethnographic and netnographic (Kozinets, 2015) description and interpretation, informed by findings in previous studies of the life conditions of deaf people and people with cognitive disabilities, led to the enquiry around which this chapter is organised. This inspired the combination of theories interrogating assumptions about ability, deafness and language use in digital contexts. The materials collected include field notes from meetings, open letters, social media posts and newspaper articles on conditions and consequences of imposed regulations, governmental agency announcements, communication to university employees and participant observation in online courses and activities. We employ examples of pandemic-related changes and restrictions based on materials used in our earlier work as well as for the purpose of this collaborative project. This has resulted in the development of the notion of language (in) accessibility, which emphasises the processual, non-dualistic nature of how social arrangements grant or deny access to populations.

One of the authors is a member of the Stockholm University working group on issues regarding the deaf and hard-of-hearing and Swedish Sign Language (DH-STS) in respect to accessibility and higher education. As course organisation questions about moving online began to be actualised at the university and solutions were offered to adapt to the restrictions, attention was brought to the DH-STS working group by students, employees and organisations outside the university. As discussions developed within DH-STS as well as with university leadership, material was collected for two objectives: to ensure accessibility and to study the exchanges about the measures which gave rise to adjustments as well as to new obstacles. Initially the documentation and collection of material was used to exemplify the implications of new policy implementation for deaf people's access when meeting with university leadership. This dual nature of the objectives is also reflected in the dual nature in academic activism (see also Apelmo \& Nordgren's chapter for a discussion on their autoethnographic position).

Another of the authors is involved in the Participatory Action Research collective, and works for its consultancy arm, Begripsam, ${ }^{1}$ which draws on members' own lived experiences of cognitive and perceptual impairments or difficulties. The aim of the consultancy, the collective and the research is to improve access to and usability of devices and structures in digital society for citizens at large and citizens with cognitive difficulties specifically. Simultaneously, the collective is testing and developing methods for such research and implementation in cooperation with the Royal Institute of Technology, $\mathrm{KTH}$, Stockholm, and the Department of Design at Lund University. To achieve this, methods of cooperation have to be developed through collaboration (by academic researchers, designers, developers, social agents of change and co-researchers-as-users) working to educate each other in digital and web literacy (Johansson, 2019). This process creates a shared knowledge 
of internet use, digital literacy, participants' difficulties and needs as well as how these processes of change are connected to accessibility and full participation. During the COVID-19 outbreak the work process took on a whole new dimension, when developing this knowledge occurred simultaneously with needing to use that knowledge: needing to get online to learn how to get online.

\section{Ableism, linguicism and audism}

To unpack the relationship between disability, deafness and language use, we turn to the oppression triumvirate of ableism, linguicism and audism. ${ }^{2}$ Ableism is the idea that able-bodied (healthy) persons are preferable and superior to those who are considered non-abled (the disabled) (Campbell, 2009). Linguicism is a form of 'linguistically argued racism' according to linguist Tove Skutnabb-Kangas (2000) who coined the term, as opposed to biologically or culturally argued racism as in ethnicism or culturalism. Audism, which is the oppression of the deaf, their communication in sign language, and as a result their culture, intersects with the previous two systems (Bauman, 2004).

Ideologies, practices and structures promoting the idea of a 'correct' language (re)produce an unequal division of power and resources (both material and immaterial) between groups (Skutnabb-Kangas, 2000). There are ideas about being able to comprehend through communication and language that border on not being seen as weak, inferior, unlearned or not 'of sound mind'. Those who are said to have excellent speaking skills or command of the language create the hierarchy and resulting inequality of linguicism. Take for example resolving a breakdown in communication. This requires both sides to locate a problem which has to do with misunderstanding to which each contributes. Linguicism attributes fault to one side, the minority side: the person or group lacking in capacity in the dominating language. This linguicism is due to a lack of perspective about other types of communication and linguistic systems that differ from one's own, and is a clear example of where inaccessibility emerges.

Audism, as a subset of both ableism and linguicism, interrogates taken-forgranted ideas about why it is better to talk than to sign, a view that positions deafness as inferior to hearing. It is important to understand in reference to accessibility and language for people who are deaf and communicate in a signed language the interrelated notions of audism and ocularcentrism ${ }^{3}$ (sight-centredness), which is at the centre of being deaf, in that it entails what it means to experience the world through vision, as well as separatism. Being separate, from the perspective of the deaf sign language community, emphasises that they often feel most included in everyday signing environments which are apart from the mainstream, rather than feeling isolated from the latter, as hearing people often perceive it. This negative understanding is due to the lack of knowledge about the harms of audism, which perceives deaf people as inferior because many do not use hearing and speech. Audism also comes into play in the provision of interpreting services into sign language, 
and is why text-based translations should be viewed not as making spoken language accessible, but as a special type of exclusion which is based on withholding the opportunity to use the only natural language that is fully accessible to deaf people.

The prioritisation of digitalised accessibility replacing sign language interpretation (i.e. closed captions in Swedish instead of interpreting in sign language) is a particularly illuminating example of the Swedish legislation on language status and minority language rights being conflated with an adjustment for a disability group the hard-of-hearing who use Swedish and not Swedish Sign Language (STS). The legal protection for STS as it stands (March 2021) is primarily about the right to a certain kind of bilingualism: to learn sign language first and then Swedish, the right of children (hearing or deaf) of deaf parents to mother tongue education in sign language, and that deaf people, to some extent, have access to interpretation in certain everyday situations. In Sweden, sign language is juridically neither considered a mother tongue (unless your parents are deaf) nor a minority language, but is stated to be the first language of deaf people and granted a certain level of special protection from the authorities. However, in which instances (or to what length) this protection is granted is not clearly specified (SOU, 1997:192; SFS, 2009:600; SOU, 2019:18). In the discourse of the public authorities, sign language rights are primarily linked to an expression of the need for an alternative means of communication as a result of an impairment rather than a linguistic cultural affiliation (Larsdotter et al., forthcoming).

This brings us to the point of the often-taboo subject of talking about deafness as a disability (Lane, 2002). Difficulties to read, write, and comprehend in Swedish in this case can have different origins. Conflating cognitive disability groups with language minority groups without sensitivity to these origins is related to the harm of audism and ableism through linguicism, and the hierarchies they create. If a person does not have the physical anatomy to use sound and is deprived of acquiring a visual-gestural language, it will result in a cognitive disability. This lack of access to human sign language, with its adverse and long-term consequences, makes it very difficult for hearing people to begin to untangle what disability vis-à-vis lack of hearing is and is not. (For a discussion of delay versus disorder in deaf and hard-of-hearing populations see Matthew Hall, 2020.) The main complicating factor in comprehending this difference is the notion of 'deafness as disability' from a majoritarian perspective, making it difficult if not impossible to understand capital 'D' Deaf. ${ }^{4}$ These are people who belong to a signing deaf community, either from birth or through relationships formed with members of such a community, and want to be deaf in a cultural sense and stay securely connected and immersed in a sign language-based Deaf culture. This contrasts with the majority (hearing people's) view of being deaf (with a lowercase 'd'), which is defined by social (barriers to sound) and medical (measurements and levels of hearing) models of disability. In essence, the claim is that the deaf are those individuals who cannot hear. What divides Deaf and deafness groups is 
the languages and modalities they use. In addition, hard-of-hearing people form a subset of hearing people who hear less well, but who nevertheless share the dominant language and culture. This means that, when referring to the deaf and the hard-of-hearing, we are in fact always talking about two distinct language-using groups (see Obasi, 2008). Yet these two different language communities: hard-of-hearing Swedish speakers and deaf STS signers, are often placed in a single disability category.

Moreover, medical definitions place hearing impairment on a single continuum (from hearing to not hearing), which leads to the common misconception that their communication is on a corresponding continuum from more Swedish to less. That continuum fails because Swedish and STS are two distinct natural languages, with no continuum between them. Hearing people very commonly hold this misconception about the culturally deaf and their visual-gestural language modality (Adams Lyngbäck, 2016; Higgins, 1980; Padden \& Humphries, 1988). Not only are Swedish and STS as distinct and unintelligible to one another as English and Korean, the different sensory skills needed for spoken and signed languages set them worlds apart (Bellugi, Poizner \& Klima, 1989).

Combating ableism, audism, linguicism, and their combined effect in the form of language inaccessibility depends on fighting against inequities from a number of standpoints in disabled, deaf and minority language communities. This is done by first revealing then intervening, instead of, for instance, waiting for an institutionalised form of fairness by the authorities. This cultivates the practice of an 'active equality' (Colton \& Holmes, 2016). How society responds to a crisis or disaster illuminates inequity (Uekusa, 2019), which is why we begin by presenting the exclusionary effects of an urgent and longlasting crisis - the COVID-19 pandemic - to show how a lack of social justice in education contributes to oppression by denying language access.

\section{Signing in (of) a crisis}

In their observations on how COVID-19 information was made available, the Swedish National Federation of the Deaf (SDR) and National Association of Deaf, Hard-of-Hearing and Language Impaired Children (DHB) were quick to point out the lack of accessible information in the frequent news conferences held during the spring of 2020 with representatives of the Swedish Public Health Authority and the Swedish government, which gave citizens statistical information about new recommendations and directives. The press conferences quickly developed into a recurring nationwide event and were followed by 'everyone' to know how to protect themselves, their families and friends, local communities and society more broadly. But, as is often the case, the mode of communication, and the type of language used at the press conferences, was not accessible to all (adults) in the country, even though all were supposed to follow the recommendations. Thus, the press conferences renewed the visibility of the barriers to access of information in a time of 
crisis which marginalised groups face, such as the disabled and non-dominant-language users. In an open letter to a number of national authorities ${ }^{5}$ the SDR wrote about the 33 days during which no information was provided in STS by the authorities during the crisis, and how the preceding state of events had led up to yet another failure to provide public service announcements and information for the safety of signing deaf citizens. The responsibility yet again fell on civil society and activist organisations to provide interpretations or translations. This campaign for accessibility in the communication of emergency information by the Swedish authorities has its roots in the 2017 terrorist attack in Drottninggatan, a major shopping street in downtown Stockholm. That was when the organisation ramped up its demand that officials have resources in place in the event of future crises, a demand which was partly successful.

In spite of the progress made after 2017, the lag in information provision and the blockages in channels for adapting the COVID-19 emergency press conferences persisted. Once this situation improved, and materials were produced, DHB and other organisations ${ }^{6}$ were quick to point out issues related to comprehensibility in Swedish and STS in the information. This example shows the ingrained persistence of ableism, linguicism and audism which prompted all of these organisations to act, point out oversights and produce appropriate materials. An ableist view assumes that these groups should get their information second-hand, through assistance and in a language not fully accessible to them in a crisis which requires as clear and accurate information as possible. Instead, it took many weeks and even then continued to be difficult to secure acceptable levels of accessible information. This shows that even though the laws and regulations for equal access are in place, language inaccessibility persists even in critical conditions. Once the knowledge of language accessibility (and the knowhow required to achieve it) was redistributed, and manifested in live broadcasts in the form of sign language interpreting (for the deaf) and closed captioning (for the hard-of-hearing), the reporting and press conferences on the COVID-19 situation were at least in a form that reached these groups at the same time as the hearing and Swedish-speaking public.

But why is it still the case that it is necessary to struggle to gain access to information? SDR and DHB, non-governmental/activist organisations which prioritise language access issues, are the ones providing the adaptations and not the national authorities. ${ }^{7}$ The information from the government and public organisations is directed towards the centre of the population and its imagined standard of language. As STS is still not recognised as equal in status to one of the spoken minority languages, the language rights of people with sign language as their main or first language are expressed in the Language Act as similar to a language that shall be protected and safeguarded by the public (SFS, 2009:600).

Institutions fall short of ensuring the participation of all citizens precisely in moments when communication becomes a moral responsibility. People in positions of power and influence decide what is determined to be in the 
national interest or what constitutes a public health emergency. It is not entirely clear if these decision-makers reside within media companies, the authorities or the political bodies, contributing to the opaqueness of who exactly misses the mark on accessibility. The example of the COVID-19 information shows that there were lines drawn between those who hear and those who don't use sound, between subgroups with different disabilities within them as well as between majority and non-majority language users. The language and ability subgroups reached in a crisis construct the de facto 'national interest' and equate it to the 'interest of the norm' in the form of language and modality used as well as adaptations made for disability. Those who are reached by the message are those who hold a particular set of abilities and capabilities resembling those held by the sender representing the government of the nation. Who of those residing in a certain geopolitical area are being addressed, about what, and when? This enquiry reveals how the parameters of language inaccessibility are inadvertently shaped.

We can view this example of language inaccessibility as knowledge 'out of place'. The communication and language conditions of these groups are known but are not prioritised on the necessary agendas until, first, the consequences are made obvious and blatantly clear and/or, second, the knowledge falls in place. The question of creating accessibility necessarily lies with those who are responsible for democratic and just treatment of all parts of the population. The national authorities and the governing bodies determine what is in place and out of place through how they allocate funds to employ people with competence in providing accessible communication. Those in power control the discourse and the subsequent activities to be undertaken. To keep the position of 'the ones who govern', they are obliged to negotiate (Fairclough, 2015). As this example of access to information in crises shows, a newly won struggle is only temporarily resolved because it is repeatedly subject to negotiation. In the words of the political activist, philosopher and academic Angela Davis (2016) 'freedom is a constant struggle', as the next example will illustrate.

\section{Text versus sign language}

With the COVID-19 outbreak, in March 2020 Swedish universities called for all classes to move to online instruction. The crisis led to lectures being recorded using videoconferencing services on a far greater scale than ever before. These organisation-wide changes actualised difficulties about the directives regarding interpreting and closed captioning of text or signing. For deaf students it was decided that all instruction in real time would be signlanguage interpreted according to the course schedule. For deaf and hard-ofhearing students all recorded course material would be subtitled by each department. The reason for the closed captioning of all recorded teaching materials was that instruction had to be as accessible for deaf and hard-ofhearing students as it was for hearing students (we will return to this audiocentric misunderstanding below). 
Between the initial outbreak of the virus in mid-March and 1 May, exceptions were made to the interpreting rule (that only 'real-time' instruction would be interpreted to sign language) since it was a practical impossibility for the sheer volume of new material to be closed captioned for students who otherwise use interpreters. Instead these materials, in courses where deaf and hard-of-hearing students were enrolled, were equipped with recorded sign language interpreting. Thus, for the first six weeks of the pandemic closures, interpreters were available both for classes delivered on video conferencing platforms as well as for the pre-recorded lectures that were being produced.

However, during the autumn semester in 2020, directives about sign language interpretation were given and a new situation arose. Under the new directives, when a pre-recorded lecture has been equipped with closed captions, deaf students no longer have access to interpretation of its content. Thus, a central misunderstanding, namely that closed captioning is an adequate replacement for interpretation into STS became an accessibility rule of thumb. What this revealed was the mixing up of two issues: one regarding closed captions and the other access to sign language interpretation, a conflation of accessibility measures that emanates from a hearing norm. This led to the persistence of a form of audism from before the onset of the COVID19 outbreak, which broke down into a blatant example of discrimination which remains difficult for the responsible authorities to comprehend, because they are hearing. ${ }^{8}$ If a hearing person is able to listen (and see and read) a lecture, to have equal access through interpreting, the deaf person is able to 'sign read' or listen with the eyes or vision: syssna, derived from the word lyssna, 'to listen' in Swedish (Institute for Language and Folklore, 2019).

Students have pointed out to the DH-STS working group at Stockholm University, as well as in online discussion forums in deaf organisations, ${ }^{9}$ that closed captions of lectures in informal speech as well as formal academic language, are at times extremely difficult to decipher. This is exacerbated by the poor quality of the digital image the subtitles appear on, as well as the use of simultaneous PowerPoint presentations with text that may be obscured by the running closed captions at the bottom of the screen. Deaf students must resort to reading their way through their educational programmes in multimodally presented sub-standard Swedish, which is not even their primary language. Even worse, there were occasions where students were told to individually apply for sign language interpretation for each lecture, unit or event as a special case of need due to an additional disability and, after applying, some even had that request rejected. In light of the unfair conditions for deaf and hard-of-hearing students, hearing instructors became aware that if they pre-recorded their lectures these groups would not have equal access and would be at a disadvantage.

Participating in a pre-recorded lecture equipped with text in closed captions requires deaf students and deaf teachers to constantly switch between two different languages: Swedish (closed captions) and STS. This leads to a heavier cognitive effort and brings with it a higher likelihood of 
misunderstanding and miscommunication. Moreover, the interpreter takes over the paralinguistic features of talk, including stress, tone and liveliness, etc. - all this is lost for deaf people who do not have access to sound alongside captioning, which further complicates their access to the content. ${ }^{10}$

Confusing language interpretation between two different languages as interchangeable with providing multiple modalities of a single spoken language is a mistake often made by hearing individuals for a number of reasons. The understanding of a deaf person's literacy in a second language as primarily a language used in a written form builds on knowledge of sign linguistics, deaf education competence and perspectives from deaf lives, and is rooted in an acknowledgement of their experiences as legitimate forms of knowledge.

At the end of the autumn term in 2020, a document entitled 'Sign language interpreting of pre-recorded lectures replacing live lectures in campus-based courses during 2021' was sent to Swedish universities and colleges as well as individual programme providers with permission to issue degrees. The sender of the document was the administration for national funds for targeted educational support at the Ministry of Education, and the document was based on consultations with the national reference group consisting of representatives from higher education institutions for this purpose. There was no consultation with the DH-STS working group prior to the decisions leading to these changes, but the group was informed in a joint meeting as a result of the pressure it had exerted. Briefly, the document recommended that as long as COVID-19 conditions persist, and restrictions are in place, students should have access to sign language interpretation of lectures regardless of format. Instead of letting 'in real-time' or 'face-to-face' determine which lectures are interpreted, it is the form of programme as 'campus-based' which is used to support the argument to allow for exceptions to accessing interpreting services for pre-recorded lectures, i.e. when it replaces a live lecture which was supposed to have been sign language interpreted in real-time. Thus, the crisis made it possible, for the second time, for an exception to be made. Earlier in the year, when the restrictions first went into effect, the Office for Interpretation Services made the first exception that interpreters would work online and with pre-recorded lectures as it was deemed to be reasonable as well as fair to do so. Now, a second exception based on consultations with deaf students and special-interest groups enabled a broader range of lectures to be interpreted, regardless of whether they were live or pre-recorded.

\section{Digitalisation: going online to get online}

During the COVID-19 pandemic, when upper-secondary schools and further education were called to move to online education, students with intellectual disabilities were not included as their participation in digital education was not seen as possible. As ableism and linguicism coincide as pervasive systems, the question of who gets access to what in schools in terms of instruction has 
to be examined in terms of what (digital) literacy is understood to be. Several studies have shown how students with cognitive disabilities are not afforded opportunities to develop languages, literacies and use content-specific tools (Berthén, 2007; Reichenberg, 2012; Martínez-Alvaréz, 2019). This body of research shows that normative ideas about what (both digital and non-digital) language use entails affects what students with intellectual disabilities are afforded to learn. There is, in addition, a perceived (in)ability of students to participate in (digital) literacies and language use, which creates hindrances to future participation due to a lack of teaching. However, action research (Johansson, 2019) has highlighted and actively works for enhanced possibilities for groups which were previously excluded from being able to participate in digital literacies.

When the pandemic hit, the research collective Begripsam, which focuses on digital literacy by being directly involved in making digital services understandable and 'user-friendly', had to go all-digital. The pandemic revealed that being able to 'go online' was assumed to be a skill everyone possessed. This assumption builds on the presupposition that everyone receives what is required to be able to do so in their basic education.

One of the ongoing Begripsam projects involved adult former students of special education, with low literacy skills, participating in the development and design of an accessible digital learning platform. This group represents the kind of students who, in the secondary school lockdown, were not expected to be able to participate in distance learning. With the onset of the COVID-19 outbreak all Begripsam workshops, including training courses for designers of web accessibility, had to co-occur because all participants now had to attend remotely from their homes which entailed 'going online to get online'. This was overcome by providing alternative instructions in several modalities (written, spoken and filmed) and extra one-on-one resources. Within days, all participants were online from their homes. These seemingly insurmountable obstacles were cleared by tapping into an already existing (though still under development) structure and organisation. Testing in a reallife situation produced a long list of valuable insights which would most likely not have been detected otherwise. The most obvious one being that one cannot be expected to master something in which one has not been instructed. It is not the ability of students in special education settings that primarily sets the boundary for what they can learn but the level of adequate teaching that makes learning possible.

The absence of such teaching by the most qualified teachers who can analyse the conditions required for concept development is a consequence of the intersection of linguicism and ableism. Far too many schools and other educational efforts for students with cognitive disabilities fail to recognise that digital competence and being able to communicate digitally are important life skills for everyone. There is either a lack of knowledge or priority, or both, that it is possible for students with cognitive disabilities to learn how to use digital technology and participate in digital literacies. Revealing these 
oversights and misconceptions can bring change in teaching practices, making it possible for people with cognitive disabilities to participate in online communication - as shown in the example from Begripsam. Also, knowing what can go wrong (since it did go wrong) acts as a feedback loop in developing activities and systems. What to expect and what to do in the event something goes wrong is the primary focus of comprehensibility of digital services, instead of perceiving situations where digital communication does not work as dependent on the cognitive abilities of the persons involved.

\section{Conclusion: changing the question}

The COVID-19 pandemic created new barriers as well as new possibilities for inclusion, as shown in the empirical examples discussed in this chapter. All three examples make visible how hindrances that are created by not being taken into account by the majority society can be overcome - but the driving force behind removing obstacles are activists, interest groups and those who are themselves affected. For instance, the example on participation in digital education for people with cognitive disabilities shows that ideas on who can use digital technology creates barriers for participation in online education. Linguicism and ableism saturate teaching practices where students with cognitive disabilities are not offered instruction in how to use digital technology for communication and participation in education, and thus, during the early part of the pandemic, it was believed that these students could not participate in online education like others in the same age groups who were moved to online instruction. But, as the example from Begripsam shows, it was indeed possible if and when adequate instruction and accessible digital devices and content were provided.

Similarly, it was the actions of non-governmental organisations that made the lack of access to COVID-19 information visible and led to the adaption of communication modes. It was the deaf and hard-of-hearing students themselves who raised their voices about the difficulties of participating in education during the move to online education, as sign language interpretation during live lectures was replaced by closed captioning of pre-recorded lectures. With the help of a special-interest organisation, a temporary change in regulations was put into place.

These examples show that communication solutions as well as obstacles are due to societal choices and priorities, and not because of a false notion that certain types of bodies individually and independently create the conditions or that one standardised solution will fit all. Ableism, audism and linguicism can take the form of institutionalised discrimination, for example how government services such as COVID-19 information or participation in online education due to the pandemic are made inaccessible to people with disabilities, the deaf or minority language users. As these are systems of oppression, and inaccessibility is a form of limiting freedoms we use the notion of 'institutionalised inaccessibility' to refer to how the majority in society 
constitutes the limits and boundaries for its citizens in how attitudes and beliefs shape decisions in institutions.

Accomplishing affirmative social change can come about through responses to a crisis such as the pandemic but this also requires multiple forms of transformation. There is a clear tendency to see digitalisation and technical development as inevitably good for accessibility. This conceals the fact that one size does not fit all and that digitalisation and technical development can be formed in many different ways to fit groups and individuals not taken into account in current digital practices. This invisibility helps reinforce commonly agreed upon practices (cf. Winther Jørgensen \& Phillips, 2000) that promote institutionalised inaccessibility in the form of ableism, linguicism and audism.

To remedy inequalities, taking empirical examples of what happens in response to a crisis requires studying consistent forms of social discrimination at a structural level and how they play out in everyday lives as Shinya Uekusa (2019), a sociology of disaster scholar at Aarhus University, concludes. An uneven distribution of negative consequences may come as a surprise to some, but seldom to those who hold subordinate positions in hierarchies, as discussed in this chapter. Successfully contesting the current social order to promote changes demands action, but the groups being oppressed, disadvantaged or discriminated against are left with the task (of educating, of mobilising, of defending, of struggling), as is evident in all three examples.

Our examples of language inaccessibility in this chapter provide lessons that must be constantly retaught since, even though we believe we are democratic, the system does not take everyone into account. Even when adaptations and accommodations are made in what is believed to be an inclusive way - as in the example of closed captioning of online lectures - just following guidelines and checklists seldom suffices. Providing closed captions in text, now that it is required and made technically possible on a large scale, was a huge feat but even new and improved universal solutions will always require novel and particular accommodations. Realising the continuing process of 'literacy of accessibility' is part of being socially literate in matters of difference and disability.

Here it is useful to consider the work of Ann Curry-Stevens (2007), a scholar of adult education and social work, who provides a description of a knowledge process that rests on three pillars: equity, activism and social literacy. Social literacy requires the development of awareness of one's own position and connection to others unlike oneself in structural power relations (Kimmel \& Ferber, 2014). Our shared goal in an accessible society is accurate learning about disability as a relation between socially constructed conditions and minority bodies (Evans, Assadi \& Herriott, 2005; Barnes, 2016). This challenges us all to be, on an individual level, willing, open and capable to be 'uncomfortable' in coalitions with others unlike oneself, utilising what philosopher Erinn Gilson names epistemic vulnerability (2011), i.e. valuing the precarious position by admitting to not knowing, being willing to learn from others and valuing others' experiential source of knowledge. Gilson defines 
this as the active choice of being open to not knowing (for example what harms or limits people who have a cognitive disability or who are deaf), to being open to possibly getting it wrong and getting corrected, and a willingness to enter situations of not knowing. Vulnerability in this sense is not an individual feature nor a negative state; rather, it is a potential for change by being affected and affecting others (Snyman, 2015). Getting it wrong but being willing to acknowledge being wrong and ready to be 'disturbed' by becoming the 'Other' (Gilson, 2011) is how to go about 'righting' that wrong. But because it is difficult to embark from ignorance since it hurts, this gets ignored or, worse, the blame is placed on the excluded group for making others feel bad (cf. ibid.). This tendency can be named invulnerability in its worst form: people in power who are unknowing and resist change to avoid feelings of guilt and consequently harm others.

There is a fundamental stubbornness inherent in inaccessibility, as linguicism, ableism and audism are immanent features in so many of our institutional practices such as education. Being excluded from education closes off from community in the long term; being excluded from health information about a dangerous virus can permanently separate from community through illness or death. Connectedness to others' lives is a required condition to gain knowledge. Calls and actions for change, on the other hand, draw on knowledge sources that are underutilised and under-theorised. Proficiencies which are perspective-based operate by illuminating how others' agendas are connected to our own, often historically. Being in coalitions requires valuing the necessity of discomfort (having to make mistakes), calling attention to one's own ignorance as a source of oppression, realising how another person's bodily dimension of knowing is key to seeing oneself and one's own learning (Logue, 2013). Knowledge, in the form of epistemic vulnerability, is needed for illumination, since inaccessibility as a phenomenon is enacted in new and obstinate forms for each situation in which it arises.

We conclude by insisting that at least the questions about inaccessibility be changed. The barriers are well-known and researched. Still, change doesn't occur. What has yet to be explored is what unites a will for change and how coalitions between different groups form to present united fronts and political will by holding together: a common threat makes for a common goal.

\section{Notes}

1 Begripsam is a play on words combining the Swedish for 'to understand', att begripa, in its imperative form begrip! with an abbreviation of the nouns for 'society', samhälle and 'together', tillsammans. At the same time the suffix -sam may indicate a 'condition', thus making Begripsam equivalent to 'Understandable' or 'Understandish'.

2 Ableism (Campbell, 2009), linguicism (Skutnabb-Kangas, 2000, 2002), audism (Pelka, 1997; Bauman, 2004; Bauman, 2008; Eckert \& Rowley, 2013; Reagan, 2020).

3 Ernst Thoutenhoofd (personal communication 27 August 2020) describes ocularcentrism in Ocularcentrism and Deaf People: A Social Photography Project 
(1997) as how deaf perceive the world and because of that develop signed languages, not the other way around. Later works on Deaf Pride, Deaf Gain and Deafhood build on similar notions.

4 Capital ' $D$ ' deaf and deaf in an audiological medical perspective are distinguished by the notion of culture, a shared language and pride united through experiences of audism, ocularcentrism and separatism (E. Thoutenhoofd, personal communication, 15 August 2020) as opposed to diagnoses and categorisations based on the difficulty or inability to hear.

5 The Swedish Public Health Authority, Swedish Civil Contingencies Agency, Healthcare Guide 1177, and Swedish Public Service Television. Healthcare Guide 1177 is a site for information and e-services for the public on health and healthcare by Swedish county councils and regions.

6 Many organisations mobilised resources to communicate information in suitable formats on their websites in response to the COVID-19 pandemic. FUB, the Swedish National Association for People with Intellectual Disability (FSDB), the organisation for the Deaf-Blind in Sweden, and the Swedish Aphasia Association all responded with information for their members in online articles such as 'Advice for people with deafblindness and relatives about the Corona virus and Covid-19' (30 March 2020).

$7 \mathrm{DHB}$ is a coalition for the political interests of different groups based on contrasting communication systems and accommodations including intellectual or cognitive disability and multiple disabilities in combination with sign language, Swedish or other commonly used minority languages.

8 In the discourse of the authorities, sign language is, admittedly, the first language of the deaf. However, in the subcommittee study in preparation for minority language legislation referred to in the works leading up to the approval of the Language Act, the authors argue that they believe that, 'even if the deaf themselves see themselves as a linguistic and cultural minority', sign language is primarily 'a way [...] to be able to communicate with the surroundings despite their disability' (SOU, 1997: 192, pp. 94-96, our translation).

9 In one online Facebook discussion forum, hard-of-hearing students, who also sign, raised concerns that texting would be taken away in favour of sign language captioning. The situation, content, type of presentation as well as the personal preference of the bilingual/bimodal/multilingual learner all determine what is considered 'quality accessibility' for members of these communities.

10 Even more long-term implications are connected to the reduction of interpreting between Swedish and STS. A deficit in linguistic parity arises: new concepts and key ideas in abstract terms also are required in sign language, which is a very important aspect of interpretation in higher education and in research.

\section{References}

Adams Lyngbäck, Liz (2016) Experiences, Networks and Uncertainty: Parenting a Child who Uses a Cochlear Implant. Doctoral dissertation, Department of Education, Stockholm University.

Barnes, Elizabeth (2016) The Minority Body: A Theory of Disability. Oxford University Press.

Bauman, H-Dirksen L. (2004) Audism: Exploring the Metaphysics of Oppression. Journal of Deaf Studies and Deaf Education, 9(2): 239-246. doi:10.1093/deafed/ enh025.

Bauman, H-Dirksen L. (2008) Introduction: Listening to Deaf Studies. In: H-Dirksen L. Bauman (ed.), Open Your Eyes: Deaf Studies Talking, Minneapolis: University of Minnesota Press. 
Bellugi, Ursula, Poizner, Howard, \& Klima, Edward S. (1989) Language, Modality and the Brain. Trends in Neurosciences, 12 (10): 380-388. doi:10.1016/0166-2236(89)900763 .

Berthén, Diana (2007) Förberedelse för särskildhet: Särskolans pedagogiska arbete i ett verksamhetsteoretiskt perspektiv. Doctoral dissertation, Estetisk-filosofiska fakulteten, Karlstad University.

Campbell, Fiona (2009) Contours of Ableism: The Production of Disability and Abledness. New York: Palgrave Macmillan Press.

Colton, Jared S. \& Holmes, Steve (2016) A Social Justice Theory of Active Equality for Technical Communication. Journal of Technical Writing and Communication, 48 (1): 4-30. doi:10.1177/0047281616647803.

Curry-Stevens, Ann (2007) New Forms of Transformative Education: Pedagogy for the Privileged . Journal of Transformative Education, 5 (1): 33-58. doi:10.1177/ 1541344607299394.

Davis, Angela Y. (2016) Freedom is a Constant Struggle: Ferguson, Palestine, and the Foundations of a Movement. Chicago: Haymarket Books.

Evans, Nancy J., Assadi, Jennifer L. \& Herriott, Todd K. (2005) Encouraging the Development of Disability Allies. New Directions for Student Services, 2005 (110): 67-79.

Eckert, Richard Clark \& Rowley, Amy June (2013) Audism: A Theory and Practice of Audiocentric Privilege. Humanity and Society, 37 (2): 101-130. doi:10.1177/ 0160597613481731.

Fairclough, Norman (2015) Language and Power (3rd edn). London: Routledge.

Gilson, Erinn (2011) Vulnerability, Ignorance, and Oppression. Hypatia, 26 (2): 308332. doi:10.1111/j.1527-2001.2010.01158.x.

Hall, Matthew L. (2020) The Input Matters: Assessing Cumulative Language Access in Deaf and Hard of Hearing Individuals and Populations. Frontiers in Psychology, 11, 1407. doi:10.3389/fpsyg.2020.01407.

Higgins, Paul C. (1980) Outsiders in a Hearing World: A Sociology of Deafness. Beverly Hills: Sage Publications.

Institute for Language and Folklore (2019) Ny Ordlistanhttps://www.isof.se/sprak/ nyord/nyordslistan-2019.html (accessed 14 April 2021).

Johansson, Stefan (2019) Design for Participation and Inclusion will Follow: Disabled People and the Digital Society. Doctoral dissertation, Stockholm, KTH Royal Institute of Technology.

Johansson, Stefan, Forsell, Karin \& Gustavsson, Catharina (2021) Samhällsinformation under coronapandemin - för alla?. Stockholm: Begripsam. https://www.begrip sam.se/coronapandemin/.

Kimmel, Michael S. \& Ferber, Abby L. (2014) Privilege: A Reader (3rd edn). Boulder, CO: Westview Press.

Kozinets, Robert V. (2015) Netnography: Redefined. Los Angeles, CA: Sage.

KritFunk - Critical Disability Studies Network (2020) The Impact of COVID-19 on Disabled Citizens in Sweden, iHuman, University of Sheffield. https://www.sheffield. ac.uk/ihuman/covid-19-blog/disability-and-covid-19-global-impacts/impact-co vid-19-disabled-citizens-sweden (accessed 14 April 2021).

Lane, Harlan (2002) Do Deaf People Have a Disability?. Sign Language Studies, 2 (4): 356-379. doi:10.1353/sls.2002.0019.

Larsdotter, Mia, et al. (forthcoming) The Discursive Construction of Swedish Sign Language as a Language - Ableism and Linguicism in Swedish Governmental Preparatory and Legislative Documentation. 
Logue, Jennifer (2013) The Politics of Unknowing and the Virtues of Ignorance: Toward a Pedagogy of Epistemic Vulnerability. Philosophy of Education, 1 (1): 53-62.

Martínez-Alvaréz, Patricia (2019) Dis/ability Labels and Emergent Bilingual Children: Current Research and New Possibilities to Grow as Bilingual and Biliterate Learners, Race, Ethnicity and Education, 22 (2): 174-193. doi:10.1080/13613324.2018.1538120.

Obasi, Chijioke (2008) Seeing the Deaf in 'Deafness'. Journal of Deaf Studies and Deaf Education, 13 (4): 455-465. doi:10.1093/deafed/enn008.

Padden, Carol A. \& Humphries, Tom (1988) Deaf in America. Harvard: Harvard University Press.

Pelka, Fred (1997) The ABC-CLIO Companion to the Disability Rights Movement. Santa Barbara, CA: ABC-CLIO.

Reagan, Timothy (2020) Social Justice, Audism, and the d/Deaf: Rethinking Linguistic and Cultural Differences. In: Rosemary Papa (ed.), Handbook on Promoting Social Justice in Education (pp. 1479-1510). Springer, Cham. doi:10.1007/978-3-030-146252_108.

Reichenberg, Monica (2012) Gränser på gott och ont: Undervisning i särskolan förr och nu. In: Daniel Andersson \& Lars-Erik Edlund (eds), Språkets gränser - och verklighetens: Perspektiv på begreppet gräns (pp. 143-155). Umeå: Institutionen för språkstudier, Umeå universitet.

SFS (2009:600) Språklag [Language Act]. Stockholm: Kulturdepartementet. https:// www.riksdagen.se/sv/dokument-lagar/dokument/svensk-forfattningssamling/sprakla g-2009600_sfs-2009-600 (accessed15 March 2021).

Snyman, Gerrie (2015) Responding to the Decolonial Turn: Epistemic Vulnerability. Missionalia, 43 (3): 266-291. doi:10.7832/43-3-77.

Skutnabb-Kangas, Tove (2000) Linguistic Genocide in Education-or Worldwide Diversity and Human Rights?Mahwah NJ: L. Erlbaum Associates.

Skutnabb-Kangas, Tove (2002) Marvelous Human Rights Rhetoric and Grim Realities: Language Rights in Education. Journal of Language, Identity, and Education, 1 (3): 179-205. doi:10.1207/S15327701JLIE0103_2.

SOU (1997:192) Steg mot en minoritetspolitik - Europarådets konvention om historiska minoritetsspråk. Stockholm: Jordbruksdepartementet. https://www.regeringen.se/ra ttsliga- dokument/statens-offentliga-utredningar/1997/12/sou-1997192-/ (accessed on 15 March 2021).

SOU (2019:18) För flerspråkighet, kunskapsutveckling och inkludering Modersmålsundervisning och studiehandledning på modersmål. Utredningen om modersmål och studiehandledning på modersmål i grundskolan och motsvarande skolformer. Stockholm: Utbildningsdepartementet. http://data.riksdagen.se/fil/75c5e47f-14b3-4f8 b-9749-3228e1 ca879b (accsessed 15 March 2021).

Thoutenhoofd, Ernst (1996) Ocularcentrism and Deaf People: A Social Photography Project. Doctoral dissertation, Durham University.

Winther Jørgensen, Marianne \& Phillips, Louise (2000) Diskursanalys som teori och metod. Lund: Studentlitteratur.

Uekusa, Shinya (2019) Disaster Linguicism: Linguistic Minorities in Disasters. Language in Society, 48 (3): 353-375. doi:10.1017/S0047404519000150. 